\title{
Health factors among women after mastectomy
}

\section{Czynniki zdrowotne u kobiet po mastektomii}

\section{Anna Pacian, Teresa Bernadetta Kulik, Hanna Skórzyńska, Paweł Chruściel, Agata Stefanowicz, Agnieszka Dąbrowska}

Katedra Zdrowia Publicznego, Wydział Pielęgniarstwa i Nauk o Zdrowiu, Uniwersytet Medyczny w Lublinie; kierownik: prof. zw. dr hab. n. med. Teresa Bernadetta Kulik

Przegląd Menopauzalny 2013; 5: 392-398

\section{Summary}

Introduction: The need for pro-health behaviour emerges most frequently in situations of a life change, a disease or an increased risk of falling ill. Cancer usually leads to abandonment or limitation of the life activity pursued so far. Pro-health behaviour is one of the necessary conditions of returning to fitness. Poland belongs to a group of countries with an average incidence of breast cancer, but the awareness level of disease prevention is still insufficient. Mastectomy is a strenuous treatment for a woman, both physically and psychologically, and the new situation demands change in the previous way of life.

Aim of the study: The main objective of the paper was to evaluate health factors among women after mastectomy.

Material and methods: The researched material was collected using standardized research tools: Health Behaviour Inventory and List of Health Criteria. The research was conducted among 104 women after radical treatment of breast cancer.

Results: The dominant type of health behaviour was preventive behaviour $(M=3.72)$, while correct dietary habits were the least valued $(M=3.01)$. Differences were pointed out in valuing health by the respondents, depending on the examined demographic features.

Conclusions: The general health behaviour was at a level above the average $(M=86.09)$. A relation of demographic features to preferred health behaviour was observed, according to the education level $\left(r_{s}=-0.22\right)$ and duration of the disease $\left(r_{s}=0.24\right)$. The respondents put the highest value on health understood as a condition $(M=1.36)$ and not as an effect of conscious actions, and identified it with the ability to enjoy life.

Key words: mastectomy, health behaviours, health determinants, lifestyle, women.

\section{Streszczenie}

Wstęp: Potrzeba zachowań prozdrowotnych pojawia się najczęściej w sytuacjach zmiany życiowej, choroby lub zwiększonego ryzyka zachorowania. Choroba nowotworowa powoduje zwykle zaniechanie bądź ograniczenie dotychczasowej aktywności życiowej. Zachowania prozdrowotne są jednym z niezbędnych warunków powrotu do sprawności. Polska należy do grupy krajów o średniej zapadalności na nowotwór piersi, jednak poziom świadomości profilaktyki w tym zakresie wciąż jest niedostateczny. Mastektomia jest zabiegiem obciążającym dla kobiety zarówno somatycznie, jak i psychicznie, a nowa sytuacja wymusza zmianę dotychczasowego trybu życia.

Cel pracy: Ocena uwarunkowań zdrowia wśród kobiet po mastektomii.

Materiał i metody: Materiał badawczy zebrano, wykorzystując narzędzia standaryzowane: Inwentarz zachowań zdrowotnych oraz Listę kryteriów zdrowia. Badania przeprowadzone zostały wśród 104 kobiet po radykalnym leczeniu raka piersi.

Wyniki: Dominującym rodzajem zachowań zdrowotnych były zachowania profilaktyczne $(M=3,72)$, zaś najniżej ocenianym: prawidłowe nawyki żywieniowe $(M=3,01)$. Wykazano istnienie różnic $w$ wartościowaniu zdrowia przez respondentki w zależności od badanych cech demograficznych.

Wnioski: Respondentki osiągnęły ogólny wynik zachowań zdrowotnych na poziomie ponadprzeciętnym $(M=86,09)$. Zaobserwowano istnienie związku cech demograficznych z preferowanymi zachowaniami zdrowotnymi pomiędzy poziomem wykształcenia $\left(r_{s}=-0,22\right)$ oraz czasem trwania choroby $\left(r_{s}=0,24\right)$. Największą

Address for correspondence:

Paweł Chruściel, Uniwersytet Medyczny w Lublinie, Katedra Zdrowia Publicznego, Wydział Pielęgniarstwa i Nauk o Zdrowiu, ul. Chodźki 1, 20-093 Lublin, e-mail: pawelchrusciel@o2.pl 
wartość respondentki przypisywały zdrowiu rozumianemu jako stan $(M=1,36)$, a nie jako wynik świadomych działań oraz utożsamiały je z umiejętnością cieszenia się z życia.

Słowa kluczowe: mastektomia, zachowania zdrowotne, uwarunkowania zdrowia, styl życia, kobiety.

\section{Introduction}

Lifestyle, with the associated health behaviour, is shaped in the process of interaction between environmental conditions and individual behaviour patterns. These are determined by socio-cultural factors and personal traits of the individual $[1,2]$. In health behaviour we can distinguish habitual behaviour, shaped since an early age, and intentional health behaviour which largely depends on individual awareness. Pro-health behaviour emerges most frequently in situations of a life change or a developmental change, a disease or an increased risk of falling ill [3]. Cancer, however, usually results in abandoning or restricting one's current living activities. Pro-health behaviour is one of the necessary conditions of returning to fitness and wellbeing. Research proves that lack of physical activity, obesity or smoking can disturb the recovery process [4], lead to diabetes [5], diseases of the cardiovascular system $[6,7]$ or psychological and social problems $[6,8]$. Thus, aside from combating cancer, one should also care for the betterment of a woman's psyche and her return to an accepted physical condition similar to that prior to treatment. Despite more frequent use of breast conserving therapies, breast amputation is often necessary, and the new situation a woman finds herself in, forces her to change her old lifestyle, yet adaptation to efficient functioning in the conditions altered by the operation does not have to mean total resignation from the current lifestyle.

\section{Aim of the study}

The main goal of the paper is to assess health factors among women after mastectomy.

\section{Material and methods}

One hundred four women aged 50-81, with age mean $M=62.1$ years $(S D=7.0)$, took part in the survey. For the purposes of statistical analysis, the surveyed people were placed into two groups: people up to 60 and people over 60 years of age. The majority of the surveyed women (66.35\%) were married, lived in urban areas (61.5\%) and had secondary education (64.4\%). Women with duration of the disease between 6 and 10 years constituted $38.46 \%$ of the respondents. The majority of women (68.3\%) developed complications (lymphedema - 59 people, permanent/temporary nerve lesions - 26 people, inflammation of post-operative wound - 21 people or phantom pain - 20 people).
However, the analysis did not show the influence of complications on the exhibited types of health behaviour. More than $60 \%$ of respondents suffered from accompanying ailments, without any statistical correlation with the health behaviour type.

In this paper, we have employed the diagnostic poll method. The research material was gathered using two standardised tools designed by Juczyński [9]. These are: 1. Health Behaviour Inventory $(\mathrm{HBI})$ - it consists of 24 statements describing the extent and frequency of four types of health behaviour: nutritional habits, prophylactic behaviour, positive mental attitudes, and health practices. Each of the questions in the questionnaire refers to the frequency of the activities carried out in connection with health on a five-degree scale. A higher value of the final result corresponds to stronger health behaviour.

2. Health Criteria List ( $\mathrm{HCL}$ ) - it consists of 24 statements concerning health definitions which spanned three dimensions: physical, mental and social. From the total number of statements, respondents selected those they believed had the biggest impact on their health; next, they selected five of the most important criteria; and, finally, they arranged these on a scale from 1 the least important, to 5 - the most important.

The content of the aforementioned questionnaires was supplemented with a set of self-designed questions to collect demographic data (age, education, marital status, place of residence, time since being diagnosed with breast cancer, mastectomy complications, and other co-morbidities).

The surveys were conducted in Lublin, Zamość, Łęczna, Radom and Ostrowiec Świętokrzyski. They included mainly women associated with Amazon Clubs (an association of post-mastectomy women). However, only people with no cognitive disorders were qualified for the survey. The questionnaires were handed over to the respondents in person in the Amazon Clubs, and, once filled out, collected.

The selection of statistical methods used in this paper was conditional upon the type of data included in survey questionnaires. Test results values $p \leq 0.05$ were recognised as statistically significant. The survey results were subject to statistical analysis using the SPSS program.

\section{Results}

The general index of health behaviour for the surveyed group of women equalled to 86.09 (SD =10.12).

In the population that was surveyed, prophylactic behaviour was the most dominant type of health 
behaviour, while the lowest score was recorded for correct nutritional habits. The distributions of the analysed variables were close to normal distribution (Table I).

In order to assess whether the age, education and duration of disease were connected with the level of health behaviour, analyses of Spearman's rank correlations were conducted (the Mann-Whitney $U$ test was used for other variables). The Table II below shows correlation coefficients from the conducted analyses.

Correlation analyses revealed that with an increase in education level, the level of positive mental attitude decreased $\left(r_{s}=-0.22\right)$. It was also found that the longer a given woman was ill, the greater the extent of health practices she displayed $\left(r_{s}=0.24\right)$. Other correlations were statistically insignificant.

Tab. I. Descriptive statistics for the HBI scale of the surveyed group

\begin{tabular}{lcccc}
\hline Health behaviour & M & SD & S-W & $p$ \\
\hline appropriate nutritional habits & 3.01 & 0.55 & 0.99 & 0.329 \\
\hline prophylactic behaviour & 3.72 & 0.59 & 0.98 & 0.117 \\
\hline positive mental attitude & 3.53 & 0.59 & 0.98 & 0.127 \\
\hline health practices & 3.53 & 0.53 & 0.98 & 0.191 \\
\hline
\end{tabular}

$M$ - mean; SD - standard deviation; S-W - the Shapiro-Wilk test; $p$ - the level of significance for a variable

Tab. II. Test analyses of demographic characteristics and HBI scale categories

\begin{tabular}{|c|c|c|c|c|c|c|c|c|}
\hline \multirow{3}{*}{ Demographic characteristic } & \multicolumn{8}{|c|}{ Scale of health behaviour } \\
\hline & \multicolumn{2}{|c|}{$\begin{array}{c}\text { appropriate } \\
\text { nutritional habits }\end{array}$} & \multicolumn{2}{|c|}{$\begin{array}{c}\text { appropriate } \\
\text { nutritional habits }\end{array}$} & \multicolumn{2}{|c|}{$\begin{array}{c}\text { appropriate } \\
\text { nutritional habits }\end{array}$} & \multicolumn{2}{|c|}{$\begin{array}{c}\text { appropriate } \\
\text { nutritional habits }\end{array}$} \\
\hline & $M$ & SD & $M$ & SD & M & SD & $M$ & SD \\
\hline \multicolumn{9}{|l|}{ age group } \\
\hline up to 60 & 3.02 & 0.57 & 3.70 & 0.61 & 3.43 & 0.59 & 3.48 & 0.50 \\
\hline over 60 & 3.00 & 0.55 & 3.73 & 0.57 & 3.62 & 0.58 & 3.58 & 0.55 \\
\hline results & \multicolumn{2}{|c|}{$r_{s}=-0.01$} & \multicolumn{2}{|c|}{$r_{s}=-0.01$} & \multicolumn{2}{|c|}{$r_{s}=-0.10$} & \multicolumn{2}{|c|}{$r_{s}=-0.07$} \\
\hline \multicolumn{9}{|l|}{ education } \\
\hline vocational & 2.89 & 0.56 & 3.75 & 0.64 & 3.79 & 0.53 & 3.57 & 0.56 \\
\hline secondary & 3.00 & 0.56 & 3.69 & 0.59 & 3.50 & 0.57 & 3.51 & 0.47 \\
\hline tertiary & 3.14 & 0.51 & 3.76 & 0.55 & 3.35 & 0.63 & 3.57 & 0.67 \\
\hline results & \multicolumn{2}{|c|}{$r_{s}=0.12$} & \multicolumn{2}{|c|}{$r_{s}=0.01$} & \multicolumn{2}{|c|}{$r_{s}=-0.22^{*}$} & \multicolumn{2}{|c|}{$r_{s}=-0.02$} \\
\hline \multicolumn{9}{|l|}{ duration of disease } \\
\hline $1-5$ years & 3.09 & 0.50 & 3.66 & 0.70 & 3.52 & 0.69 & 3.43 & 0.53 \\
\hline $6-10$ years & 2.90 & 0.61 & 3.70 & 0.55 & 3.45 & 0.61 & 3.57 & 0.51 \\
\hline 11 years and more & 3.05 & 0.52 & 3.78 & 0.51 & 3.62 & 0.41 & 3.67 & 0.48 \\
\hline results & \multicolumn{2}{|c|}{$r_{s}=-0.05$} & \multicolumn{2}{|c|}{$r_{s}=0.06$} & \multicolumn{2}{|c|}{$r_{s}=0.05$} & \multicolumn{2}{|c|}{$r_{s}=0.24^{*}$} \\
\hline \multicolumn{9}{|l|}{ place of residence } \\
\hline rural area & 2.97 & 0.51 & 3.71 & 0.55 & 3.61 & 0.58 & 3.53 & 0.56 \\
\hline urban area & 3.03 & 0.58 & 3.72 & 0.62 & 3.47 & 0.60 & 3.53 & 0.51 \\
\hline results & \multicolumn{2}{|c|}{$\mathrm{Z}=0.55 ; p=0.582$} & \multicolumn{2}{|c|}{$\mathrm{Z}=0.01 ; p=0.989$} & \multicolumn{2}{|c|}{$Z=0.98 ; p=0.327$} & \multicolumn{2}{|c|}{$Z=0.02 ; p=0.984$} \\
\hline \multicolumn{9}{|l|}{ matrimony } \\
\hline yes & 3.05 & 0.58 & 3.77 & 0.60 & 3.48 & 0.64 & 3.49 & 0.51 \\
\hline no & 2.93 & 0.50 & 3.60 & 0.56 & 3.61 & 0.48 & 3.62 & 0.55 \\
\hline results & \multicolumn{2}{|c|}{$Z=1.91 ; p=0.234$} & $Z=1.2$ & & $Z=0.8$ & $=0.399$ & $Z=0.9$ & \\
\hline complications & & & & & & & & \\
\hline yes & 3.08 & 0.55 & 3.76 & 0.59 & 3.53 & 0.56 & 3.56 & 0.51 \\
\hline no & 2.86 & 0.54 & 3.63 & 0.59 & 3.52 & 0.65 & 3.48 & 0.57 \\
\hline results & $Z=1.7$ & $=0.077$ & $Z=1.1$ & 0.248 & $Z=0.3$ & 0.755 & $Z=0.9$ & 0.361 \\
\hline co-morbidities & & & & & & & & \\
\hline yes & 3.02 & 0.54 & 3.73 & 0.58 & 3.54 & 0.57 & 3.53 & 0.52 \\
\hline no & 2.99 & 0.58 & 3.69 & 0.61 & 3.51 & 0.63 & 3.54 & 0.54 \\
\hline results & $Z=0.2$ & $=0.841$ & $Z=0.5$ & 0.581 & $Z=0.0$ & 0.963 & $Z=0.1$ & 0.915 \\
\hline
\end{tabular}

${ }^{*} p<0.05 ; M-$ mean; SD - standard deviation; $r_{s}$-Spearman's rho; $Z$-Mann-Whitney test; $p$ - the level of significance for a variable 
Analyses using the Mann-Whitney $U$ test did not reveal any statistically significant differences between surveyed groups for particular scales of health behaviour.

The perception of health by the respondents was examined as well. The highest mean was observed for the "to know how to enjoy one's life" criterion $(M=1.36)$, and the lowest for "to drink small amounts of alcohol or none at all" ( $M=0.03)$. The distributions of the analysed variables were close to normal distribution.

Analyses of Spearman's rank correlation between the age of surveyed women, their education and duration of disease, and their assessment of health criteria was performed (Table III). We observed that as the age of respondents increased, so did the assessments of "to be able to adapt to changes in life" $\left(r_{s}=0.22\right)$ and "be responsible" $\left(r_{s}=0.25\right)$ criteria. The higher the education level, the lower the assessment of the "to feel happy most of the time" criterion $\left(r_{s}=-0.21\right)$. Furthermore, the prolongation of disease duration was accompanied by, on the one hand, an increase in the assessment of criteria such as "to be able to coexist well with other people" $\left(r_{s}=0.21\right)$, "to be able to control one's feelings and urges" $\left(r_{s}=0.20\right)$, and, on the other hand, with a decrease in the assessment of the "not to feel any physical ailments" $\left(r_{s}=-0.24\right)$ criterion. Tables III and IV contain information concerning statements which displayed statistical correlations, while in other cases no such correlations were observed.

The analyses conducted, using the Mann-Whitney test, across the place of residence, matrimony, complications and co-morbidities, and the assessment of health criteria, helped observe statistically significant correlations (Table IV). The "to eat appropriately" criterion scored higher for people living in urban areas $(\mathrm{Z}=2.12 ; p=0.034)$, while the "be responsible" $(\mathrm{Z}=2.77$; $p=0.006)$ criterion scored lower in comparison with women living in rural areas. With regard to matrimonial status, the surveys revealed that for non-married women the "not to be ill, flu or indigestion at most" criterion was more important $(Z=2.01 ; p=0.044)$ in comparison with the respondents in relationships.

What is more, it was observed that the "be responsible" criterion proved more significant $(Z=2.25$; $p=0.024)$ for people who have experienced complications than for people who have not. In turn, the "to live till reaching advanced old age" criterion $(Z=2.12$; $p=0.034)$ was more important for women who have experienced complications than for women who have not suffered from other diseases.

Tab. III. Test analyses of demographic characteristics and HCL scale statements

\begin{tabular}{|c|c|c|c|c|c|c|c|}
\hline & & \multicolumn{6}{|c|}{ Statement number } \\
\hline & & 2 & 3 & 12 & 16 & 18 & 19 \\
\hline \multicolumn{8}{|l|}{ age group } \\
\hline \multirow{2}{*}{ up to 60} & M & 1.14 & 0.76 & 1.00 & 0.29 & 0.04 & 0.14 \\
\hline & SD & 1.85 & 1.41 & 1.78 & 0.97 & 0.28 & 0.69 \\
\hline \multirow{2}{*}{ over 60} & M & 1.15 & 1.09 & 1.1 & 1.06 & 0.42 & 0.13 \\
\hline & SD & 1.68 & 1.67 & 1.68 & 1.79 & 1.08 & 0.73 \\
\hline result & & $r_{s}=0.02$ & $r_{s}=0.12$ & $r_{s}=0.07$ & $r_{s}=0.22^{*}$ & $r_{s}=0.25^{*}$ & $r_{s}=0.00$ \\
\hline \multicolumn{8}{|l|}{ education } \\
\hline \multirow{2}{*}{ vocational } & M & 1.72 & 0.72 & 1.39 & 1.17 & 0.22 & 0.00 \\
\hline & SD & 1.93 & 1.41 & 1.94 & 1.89 & 0.73 & 0.00 \\
\hline \multirow{2}{*}{ secondary } & M & 1.16 & 0.99 & 0.94 & 0.45 & 0.13 & 0.21 \\
\hline & SD & 1.80 & 1.61 & 1.67 & 1.20 & 0.52 & 0.88 \\
\hline \multirow{2}{*}{ tertiary } & M & 0.53 & 0.95 & 1.26 & 1.05 & 0.58 & 0.00 \\
\hline & SD & 1.26 & 1.51 & 1.73 & 1.87 & 1.46 & 0.00 \\
\hline result & & $r_{s}=-0.21^{*}$ & $r_{s}=0.05$ & $r_{s}=0.02$ & $r_{s}=-0.04$ & $r_{s}=0.06$ & $r_{s}=0.00$ \\
\hline \multicolumn{8}{|l|}{ duration of disease } \\
\hline \multirow{2}{*}{$1-5$ years } & M & 11.5 & 0.42 & 1.76 & 0.55 & 0.21 & 0.00 \\
\hline & SD & 1.89 & 0.97 & 2.06 & 1.39 & 0.65 & 0.00 \\
\hline \multirow{2}{*}{$6-10$ years } & $M$ & 0.85 & 0.98 & 0.83 & 0.50 & 0.33 & 0.08 \\
\hline & SD & 1.59 & 1.49 & 1.48 & 1.34 & 1.07 & 0.47 \\
\hline \multirow{2}{*}{11 years and more } & $M$ & 1.52 & 1.42 & 0.68 & 1.06 & 0.13 & 0.35 \\
\hline & SD & 1.81 & 1.95 & 1.42 & 1.73 & 0.56 & 1.17 \\
\hline result & & $r_{s}=0.11$ & $r_{s}=0.21^{*}$ & $r_{s}=-0.24^{*}$ & $r_{s}=0.16$ & $r_{s}=-0.07$ & $r_{s}=0.20^{*}$ \\
\hline
\end{tabular}

$M-$ mean; $S D$ - standard deviation; $r_{s}$-Spearman's rho 
Tab. IV. Test analyses of demographic characteristics and HCL scale statements

\begin{tabular}{|c|c|c|c|c|c|}
\hline & & \multicolumn{4}{|c|}{ Statement number } \\
\hline & & 1 & 5 & 14 & 18 \\
\hline \multicolumn{6}{|c|}{ place of residence } \\
\hline \multirow{2}{*}{ rural area } & M & 0.98 & 0.35 & 1.15 & 0.43 \\
\hline & SD & 1.64 & 1.05 & 1.81 & 0.98 \\
\hline \multirow{2}{*}{ urban area } & $M$ & 0.86 & 0.64 & 1.08 & 0.11 \\
\hline & SD & 1.67 & 1.12 & 1.64 & 0.67 \\
\hline result & & $Z=0.84 ; p=0.403$ & $Z=2.12 ; p=0.034$ & $\mathrm{Z}=0.02 ; p=0.981$ & $Z=2.77 ; p=0.006$ \\
\hline \multicolumn{6}{|l|}{ matrimony } \\
\hline \multirow{2}{*}{ yes } & M & 0.88 & 0.52 & 0.86 & 0.17 \\
\hline & SD & 1.68 & 1.09 & 1.55 & 0.69 \\
\hline \multirow{2}{*}{ no } & M & 0.94 & 0.54 & 1.60 & 0.34 \\
\hline & SD & 1.63 & 1.12 & 1.88 & 1.03 \\
\hline result & & $\mathrm{Z}=0.32 ; p=0.747$ & $\mathrm{Z}=0.20 ; p=0.842$ & $\mathrm{Z}=2.01 ; p=0.044$ & $\mathrm{Z}=1.13 ; p=0.259$ \\
\hline \multicolumn{6}{|c|}{ complications } \\
\hline \multirow{2}{*}{ yes } & $M$ & 1.10 & 0.45 & 1.04 & 0.34 \\
\hline & SD & 1.81 & 1.07 & 1.67 & 0.97 \\
\hline \multirow{2}{*}{ no } & $M$ & 0.48 & 0.70 & 1.24 & 0.00 \\
\hline & SD & 1.18 & 1.16 & 1.77 & 0.00 \\
\hline result & & $Z=1.43 ; p=0.152$ & $Z=1.66 ; p=0.097$ & $\mathrm{Z}=0.73 ; p=0.463$ & $\mathrm{Z}=2.25 ; p=0.024$ \\
\hline \multicolumn{6}{|c|}{ co-morbidities } \\
\hline \multirow{2}{*}{ yes } & M & 1.16 & 0.48 & 1.06 & 0.29 \\
\hline & SD & 1.78 & 1.15 & 1.68 & 0.97 \\
\hline \multirow{2}{*}{ no } & $M$ & $0.51 /$ & 0.61 & 1.17 & 0.15 \\
\hline & SD & 1.36 & 1.02 & 1.73 & 0.48 \\
\hline result & & $\mathrm{Z}=2.12 ; p=0.034$ & $Z=1.49 ; p=0.136$ & $\mathrm{Z}=0.37 ; p=0.708$ & $Z=0.06 ; p=0.948$ \\
\hline
\end{tabular}

\section{Discussion}

Based on the results of the conducted surveys and analyses, we can conclude that their cancer became the major factor in changing lives of the surveyed women. In this respect, the respondents revealed their illness to be a factor that changed some aspects of their lives or changed it completely. Comparable results can be observed in studies by Bulsa et al. [10], where the surveyed population regarded good health and family happiness to be the most important goals of life. The aforementioned statement was partly reflected in our own study.

Strong support, positive mental attitude and encouragement to active life should help women after mastectomy to maintain or regain life balance [33]. Physical rehabilitation has a significant influence on the mental condition of women after mastectomy. Rehabilitation should begin even before the surgery and should continue in the post-operative period. Another important factor is education of a patient in order to convince her of the need for further rehabilitation and appropriate lifestyle [11]. As the statistics show, women after mastectomy display a fairly high, individual level of health behaviour and an average extent of health behaviour in all four categories (appropriate nutritional habits, prophylactic behaviour, positive mental attitude, and positive health practices) - these results have been corroborated in studies by other authors [12].

In their studies, Chwałczyńska and Howell et al. found awareness of the need for physical activity among women after mastectomy, and, at the same time, revealed that $27 \%$ of women up to 60 and $58 \%$ of respondents over 60 years of age did not do any sports $[13,14]$. Author's own research did not reveal any significant influence of the professional status of women after mastectomy on their level of health behaviour. It was noticed that professionally active people (up to 60 years of age) and those in a matrimonial relationship, were characterised by a comparable mean of health behaviour indices in the category of correct nutritional habits and prophylactic behaviour, in correlation with those professionally inactive (over 60 years of age) and single. The differences were evident in respect of positive mental attitudes and health practices. 
What is more, as we can see, women with tertiary education were characterised by having the lowest level of assessments in the positive mental attitude category. On the other hand, the educational level of the surveyed women affected the regularity of their medical examinations. Women with tertiary education cared to book systematic check-ups of their health.

As suggested in the studies by Bulsa et al. and Nowicki et al., spouses of women after mastectomy play a substantial role in their lives. It is they who are the main, next to Amazon's Clubs [32], source of support during hardships, as well as at different disease stages and during its treatment $[10,15]$. This can stem from the fact that professionally-inactive women have more spare time and are willing to devote it to pursuing a health-oriented lifestyle. This opinion was corroborated in the results of studies by other authors [16]. The study conducted by Bąk-Sosnowska does not confirm the correlation between having a life partner with support offered by him and the fact of accepting the disease [17]. The patients with the higher education level are characterised by more optimistic evaluation of their own opportunities and more care for their health in comparison to women with lower education $[18,19,31]$.

Beyond the above, the positive mental attitudes were found to be more common among women living in rural areas than those living in urban areas. The health-oriented lifestyle of women after breast amputation manifests itself in carrying out many health-conducive activities. These include e.g. appropriate nutritional habits [20]. The surveyed women cared for following rational nutrition practices, avoided consuming too much salt and food preservatives, and tried to avoid the consumption of animal fats and sugar. Women after mastectomy often included vegetables and fruit in their diets - such activities decrease the risk of re-developing breast cancer [21]. The research conducted by Zieliński et al. proves that there is a correlation between obesity and the increased risk of post-operative complications [20]. According to Chwałczyńska and Skórzyńska, women after mastectomy are characterised by having substantial knowledge of post-surgery complications, anti-oedema prophylaxis and the possibility of cancer recurrence [16, 23]. As our own studies show, this awareness persuades women after breast amputation to adhere to doctor's recommendations, to undertake periodical check-ups, and avoid infections. Post-operative complications, including lymphedema of the upper limb, which is the most frequent complication after mastectomy - negatively influence the physical functioning [24], which can be the reason for decreased physical activity of the surveyed group of women and negatively affect the sense of life quality. Physical exercises after mastectomy prevent the development of painful stiffening and limitation of movement in shoulder joint and spine joints, lymphedema of the upper limb, as well as improve the general condition
[13]. Physical activity not only improves locomotor fitness of women after mastectomy, but also reduces the risk of many diseases, releases optimism and enables an objective look at problems resulting from cancer $[25,26]$. Surgical breast cancer treatment decreases locomotor activity connected with the performance of everyday activities, and hampers even more the ability to practice sports and physical recreation [27]. However, women after mastectomy do not refrain from physical activity completely. Most of them perform exercises aimed at rehabilitating the upper limb on the operated side. Undertaking physical activities by post-mastectomy women, despite some locomotor limitations, was demonstrated in both own and other studies [13]. The research carried out by Chwałczyńska and Howell et al. confirms high awareness of the need for physical activity among women after mastectomy. The authors point to the lack of time, bad economic situation, and physical restrictions as the main reasons for not performing physical activities in the group of post-mastectomy women $[13,14]$.

The women who have been ill for 6 to 10 years more frequently develop appropriate dietary habits and are more adapted to the disease than the respondents whose time from the diagnosis is 1 to 5 years [28], which may be connected with stabilization and acceptance of their current health condition.

The acceptance of one's own body, which undoubtedly influences positive mental attitude (as one of health behaviour criteria) appears to be a problem for women after mastectomy. According to Chwałczyńska et al., most women after breast amputation do not accept the changed image of their bodies. This opinion has been confirmed in the author's own studies and in research conducted by other authors $[15,29,30]$. More than half of the respondents did not fully accept their current looks, and several women could not accept the present condition of their bodies at all.

The factor which is the most mobilizing to adopt health behaviour is the value associated with health. Cancer is an experience which reveals the real value of health. The outcomes of the research show the hierarchy of values considered by women after mastectomy to be the most important in relation to health. In the research of Bulsa et al. [10], health was the most frequently mentioned and the most important value in life of women after mastectomy.

In literature, there are few references concerning lifestyle of women after mastectomy. Therefore, there is a need for further research evaluating health behaviour in this group of women.

\section{Conclusions}

1. Most respondents reach the average level of health behaviour $(M \leq 4.0)$, and the least valued category of health behaviour is correct dietary habits. 
2. The education level and time from the diagnosis are related to health behaviour in the examined group of women.

3. Health criteria preferred by the respondents prove the instrumental treatment of health, which is not usually an effect of conscious actions.

\section{References}

1. Taranowicz I. Zachowania w zdrowiu i chorobie. In: Barański J. Zdrowie i choroba. Wybrane problemy socjologii medycyny. ATUT, Wrocław 2002; 63-74.

2. Trovato GM. Behavior, nutrition and lifestyle in a comprehensive health and disease paradigm: skills and knowledge for a predictive, preventive and personalized medicine. EPMA J 2012; 3: 8.

3. Sęk H. Znaczenie zachowań zdrowotnych w psychoonkologii. In: de Walden-Gałuszko K. Psychoonkologia. Biblioteka Psychiatrii Polskiej, Kraków 2000; 7-22.

4. Burstein HJ, Winer EP. Primary care for survivors of breast cancer. N Engl J Med. 2000; 343: 1086-94.

5. Earle CC, Burstein HJ, Winer EP, et al. Quality of non-breast cancer health maintenance among elderly breast cancer survivors. J Clin Oncol 2003; 21: 1447-51.

6. Hewitt M, Rowland JH, Yancik R. Cancer survivors in the United States: Age, health, and disability. J Gerontol A Biol Sci Med Sci 2003; 58: 82-91.

7. Oeffinger KC, Hudson MM. Long-term complications following childhood and adolescent cancer: Foundations for providing risk-based health care for survivors. CA Cancer J Clin 2004; 54: 208-36.

8. Garman KS, Pieper CF, Seo P, Cohen HJ. Function in elderly cancer survivors depends on comorbidities. J Gerontol A Biol Sci Med Sci 2003; 58: M1119-M1124.

9. Juczyński Z. Narzędzia pomiaru w promocji i psychologii zdrowia. Pracownia Testów Psychologicznych Polskiego Towarzystwa Psychologicznego, Warszawa 2001.

10. Bulsa M, Czaja-Bulsa G, Foszczyńska-Kłoda M, et al. Stan psychiczny kobiet po mastektomii. Doniesienia z badań. Post Psychiatr Neurol 2002; 1: 55-70.

11. Cipora E, Pasternak K, Poźniak E. Breast amputation - tragedy and hope. Zdr Publ 2002; 112 (supl. 1): 148-51.

12. Andruszkiewicz A, Koźmińska A. Zachowania zdrowotne kobiet po mastektomii. Ann Acad Med Siles 2005; 59: 298-301.

13. Chwałczyńska A. Aktywność ruchowa a wiek na przykładzie kobiet po leczeniu raka piersi. Fizjoterapia 2007; 15: 54-9.

14. Howell A, Astley S, Warwick J, et al. Prevention of breast cancer in the context of a national breast screening programme. J Intern Med 2012; 271: 321-30.

15. Nowicki A, Kwasińska E, Rzepka K, et al. Wpływ choroby na życie emocjonalne kobiet po operacji raka zrzeszonych w klubach „Amazonka”. Ann Acad Med Stetin 2009; 55: 40-4.

16. Chwałczyńska A, Woźniewski M, Rożek-Mróz K, et al. Jakość życia kobiet po mastektomii. Wiad Lek 2004; 52: 5-6.
17. Bąk-Sosnowska M, Oleszko K, Skrzypulec-Plinta V. Psychological adaptation of mature women in the first days after mastectomy. Przegl Menopauz 2013; 2: 120-4.

18. Szadowska-Szlachetka Z, Stanisławek A, Charzyńska-Gula M, et al. Differences in the quality of life of women before and after breast reconstruction measured with the use of EORTC QLQ-C 30 and EORTC QLQ-BR 23 scale. Przegl Menopauz 2013; 3: 254-9.

19. Graja T, Grodecka-Gazdecka S. The factors affecting the quality of life of women treated for the breast cancer cancer. Prz Ginekol Położ 2005; 3: 115-20.

20. Irwin ML, McTiernan A, Baumgartner RN, et al. Changes in body fat and weight after a breast cancer diagnosis: influence of demographic, prog nostic, and lifestyle factors. J Clin Oncol 2005; 23: 774-82.

21. Kruk J. Fruits and vegetables consumption and the risk of breast cancer. Wspolczesna Onkol 2006; 10: 5: 224-30.

22. Zieliński J, Jaworski R, Irga N, et al. Clinical research. Analysis of selected factors influencing seroma formation in breast cancer patients undergoing mastectomy. Arch Med Sci 2013; 9: 86-92.

23. Skórzyńska H, Rudnicka-Drożak E, Pacian A, et al. Prophylaxis of breast cancer among women over 35. Ann Univ Mariae Curie-Sklodowska [Med] 2004; 59: 474-80.

24. Chachaj A, Małyszczak K, Lukas J, et al. Quality of life in breast cancer survivors with upper extremity lymphoedema. Wspolczesna Onkol 2007; 11: 444-8.

25. Specht MC, Borgen PI, Fey J, et al. Personal health behaviors in women who have undergone risk-reducing mastectomy. Am J Surg 2004; 188: 448-9.

26. Sagen A, Kåresen R, Risberg MA. Physical activity for the affected limb and arm lymphedema after breast cancer surgery. A prospective, randomized controlled trial with two years follow-up. Acta Oncol 2009; 48: 1102-10.

27. Ridan T, Ślęczkowska J, Sobota M, et al. Evaluation of breast cancer prevention and quality of life by women after single breast mastectomy, grouped in the "Amazons" post-mastectomy women's club. Zdr Publ 2011; 211: 32-6.

28. Kurowska K, Spierewska B. The role of adaptation to the optimal quality of life among women after mastectomy. Pielęg Chir Angiol 2012; 3: 114-22.

29. Mącik D, Ziółkowska P, Kowalska M. Self-perception of women after mastectomy as an ego defence mechanism. Comparison with a group of healthy women. Wspolczesna Onkol 2012; 16: 184-90.

30. Mącik D, Ziółkowska P. Situations connected with perceived loss of femininity: menopause and mastectomy - changes in perceiving oneself as a woman. Przegl Menopauz 2012; 16: 456-62.

31. Skrzypczak M, Czerniak U, Łaski P. Selected elements of socio-demographic status and lifestyle as factors determining subjective assessment of life in women after mastectomy. Wspolczesna Onkol 2012; 16: 569-75.

32. Kozela M, Stepaniak U, Pająk A. Membership in a breast cancer peersupport organization (Amazons Club) and depression. Wspolczesna Onkol 2011; 15: 55-8.

33. Kaczmarek $Ł D$, Sęk H, Ziarko M, Marzec M. Mechanisms of psychological resiliency in women after mastectomy. Wspolczesna Onkol 2012; 16: 341-4. 